\title{
Peran Teknologi Dimer pada Proses Manipulasi Lingkungan Hidup Tanaman Bunga Krisan
}

\author{
Dwiki Fitrianto*1, Ridam Dwi Laksono² $^{2}$ \\ ${ }^{1,2}$ Universitas PGRI Madiun, Indonesia, Fakultas Teknik, Prodi Teknik Elektro \\ e-mail: *1dwikifitrianto07@gmail.com, ${ }^{2}$ ridam83@gmail.com
}

\begin{abstract}
Abstrak
Peran teknologi untuk menunjang pertumbuhan dan budidaya tanaman dapat dilakukan dengan memanipulasi kondisi lingkungan tanaman. Proses manipulasi kondisi lingkungan tanaman dapat dilakukan dengan teknologi dimmer berbasis mikrokontroller arduino. Teknologi dimmer menggunakan sensor suhu maupun sensor cahaya untuk mengatur suhu dan pencahayaan ruangan tempat budidaya tanaman. Sehingga tanaman dapat tumbuh dan berkembang dengan baik tanpa ada pengaruh perubahan iklim maupun cuaca. Dalam hal ini, teknologi dimmer akan diterapkan untuk budidaya tanaman bunga krisan. Tanaman bunga krisan termasuk jenis tanaman hias dengan waktu pendek yang membutuhkan suhu dan pencahayaan tertentu. Dengan penerapan teknologi dimmer, diharapkan bunga krisan dapat tumbuh segar dan indah sepanjang waktu serta dapat dikembangbiakkan dalam jumlah yang banyak.
\end{abstract}

Kata Kunci: Bunga krisan, Manipulasi lingkungan, Mikrokontroller, Sensor, Teknologi Dimmer.

\begin{abstract}
The role of technology to support plant growth and cultivation can be done by manipulating the environmental conditions of plants. The process of manipulating plant environmental conditions can be done with dimmer technology based on the Arduino microcontroller. Dimmer technology uses a temperature sensor or a light sensor to regulate the temperature and lighting of the room where the plants are cultivated. So that plants can grow and develop properly without the influence of climate change or weather. In this case, dimmer technology will be applied to the cultivation of chrysanthemums. Chrysanthemum is a type of ornamental plant with a short period of time that requires a certain temperature and lighting. With the application of dimmer technology, it is hoped that chrysanthemum flowers can grow fresh and beautiful all the time and can be cultivated in large quantities.
\end{abstract}

Keywords: Chrysanthemum, Dimmer Technology, Environmental Manipulation, Microcontroller, Sensor.

\section{PENDAHULUAN}

Proses kehidupan dan kegiatan makhluk hidup termasuk tumbuh-tumbuhan pada dasarnya akan dipengaruhi dan mempengaruhi faktor-faktor lingkungan, seperti cahaya, suhu atau nutrien dalam jumlah minimum dan maksimum [1]. Fotosintesis merupakan proses dasar pada tumbuhan untuk menghasilkan makanan. Intensitas cahaya yang kurang dan lebih juga tidak baik untuk proses tersebut [2]. Tanaman krisan merupakan 
tanaman tahunan dan akan berbunga terus menerus, tetapi dibududayakan sebagai tanaman semusim [3].

Tanaman krisan dapat tumbuh dan berkembang dengan baik di daerah dataran tinggi dengan kondisi tanah lembab, gembur, subur dan bebas penyakit [4], selain itu crysantheum juga membutuhkan cukup air untuk proses perkembangannya dan pertumbuhanya akan tetapi jika terlalu banyak air juga dapat menyebabkan tanaman tersebut sulit untuk berbunga [5]. Salah satu cara untuk mengatasi pencahayan tambahan pada tanaman krisan dengan diterapkan manipulasi cahaya dengan menggunakan rangkaian dimmer yang dilengkapi dengan sensor suhu. Dengan penerapan tersebut diharapkan mampu memproduksi bunga krisan yang segar dengan kualitas yang baik dan mampu menurunkan biaya produksi produsen [6]. Rangkaian dimmer merupakan rangkaian pengatur nyala lampu dengan berbagai kondisi yakni pada kondisi nyala, lampu mampu diatur sedemikian rupa dari yang paling terang, redup/remang-remang, sampai gelap/mati [7]. Penerapan rangkaian ini dapat membantu dalam kehidupan sehari-hari dengan sedikit biaya yang sangat efisien.

Pada rangkaian ini ditambahkan sensor dengan tujuan agar mampu mendeteksi secara otomatis suhu yang berada di lingkungan sekitar sehingga mampu mengatur pencahayan pada nyala lampu [8]. Sensor yang digunakan yaitu RTD (resistance temperature detector). Pengendalian suhu sangat penting untuk mengatur sebuah alat yang akan dibuat seperti inkubator [9]. Suhu udara dan tanah sangat mempengaruhi dalam proses pertumbuhan tanaman, sehingga aplikasi dari rangkaian dimmer ini cocok digunakan untuk mengatur secara otomatis pencahayaan lampu menggunakan pendeteksi sensor suhu.

Pada penelitian ini, teknologi dimmer diharapkan dapat digunakan untuk mengatur suhu dan pencahayaan ruang budidaya bunga krisan. Pengaturan suhu dan pencahayaan ruang budidaya diatur sedemikian rupa sesuai dengan habitat hidup bunga krisan. Sehingga diharapkan bunga krisan dapat berbunga dengan baik dan segar tanpa kendala musim maupun cuaca. Selain itu dengan pengendalian suhu dan penyinaran juga diharapkan dapat mempercepat proses pembungaan bunga krisan. Hal ini juga dapat digunakan untuk meningkatkan produksi tanaman bunga krisan untuk dapat dipanen dan dijual di toko bunga hias sebagai kado atau ucapan selamat. Jadi capaian yang diharapkan pada penelitian ini adalah tanaman bunga krisan dapat ditanam pada ruangan tertutup serta dapat dibudidayakan secara komersial untuk bisnis tanaman hias

\section{METODE PENELITIAN}

Dalam kegiatan ini metode yang digunakan dengan RnD. Dimana modifikasi perangkat untuk dapat memanipulasi lingkungan hidup ruang budidaya tanaman bunga krisan ini. Dengan memanfaatkan literatur yang tersedia tentang lingkungan yang ideal untuk lingkup budidaya bunga krisan. setelah pengumpulan data - data terkait lingkungan hidup bunga krisan termasuk suhu ideal dan siklus hidupnya. Selanjutnya adalah pembuatan prototype dan konfigurasi sistem. Setelah prototype terbentuk dilakukan kalibrasi sensor terhadap lingkungan prototype yang dibangun. Selanjutnya tahap pengujian system. Alur metode yang digunakan dalam kegiatan ini ditunjukkan pada Bagan. 1 Alur Kegiatan Perancangan. 


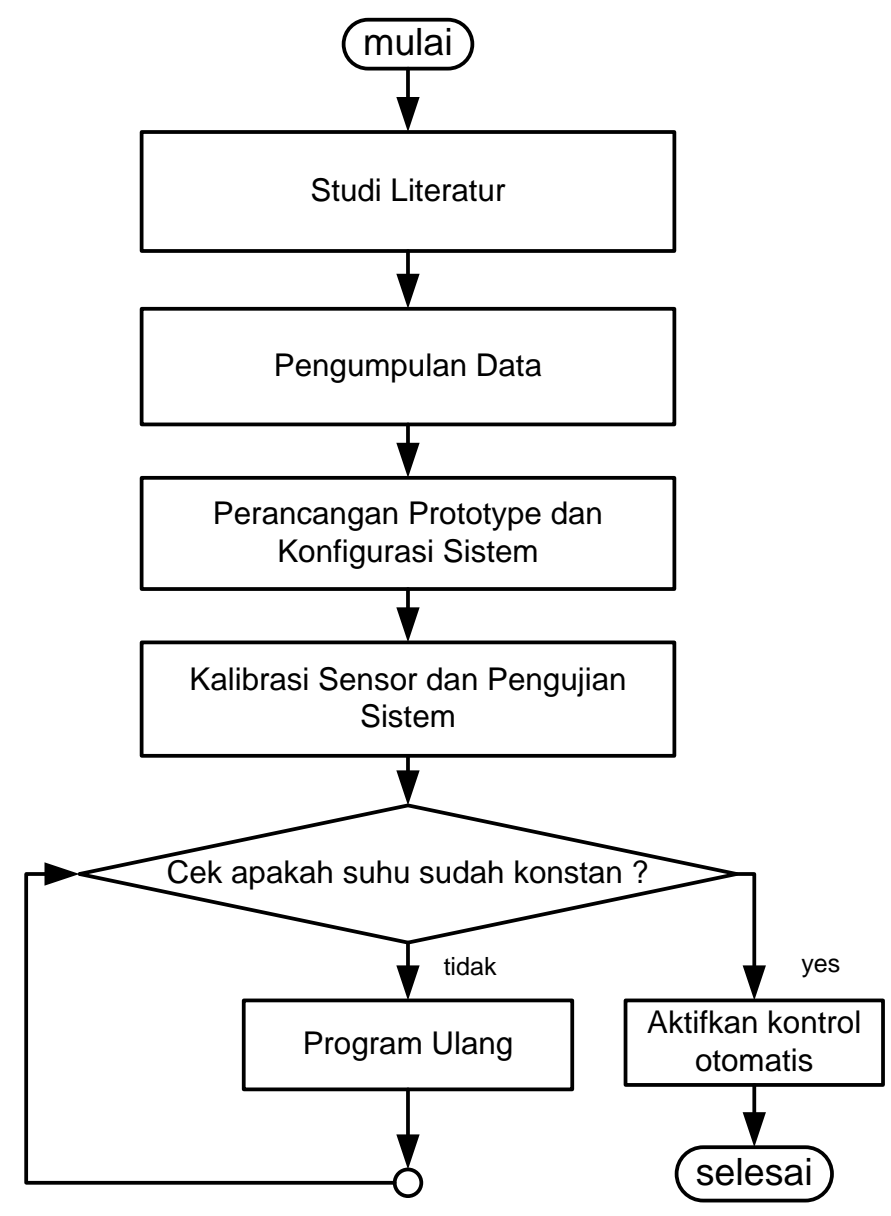

Gambar 1. Alur Kegiatan

Dari Bagan 1 alur perancangan, pada kalibrasi sensor dan pengujian sisten dilakukan dengan menyalakan lampu dengan intensitas rendah, sedang dan maksimum. Selanjutnya pada bagian pengujian sistem disimulasikan kondisi lingkungan sesuai dengan data suhu ruangan budidaya bunga krisan. Setelah data di terapkan kemudian dilakukan pembuatan program dan input program pada mikrokontroller arduino. Selanjutnya menguji kontrol otomatis dengan mengukur apakah suhu ruangan dapat dijaga konstan. Kemudian setelah suhu dapat dijaga konstan, maka sistem sudah dapat dijalankan untuk mode otomatis.

\section{HASIL DAN PEMBAHASAN}

Penerapan teknologi dimmer dalam manipulasi lingkungan hidup tanaman bunga krisan memiliki gambaran sistem seperti yang ditunjukkan pada gambar 1 . Sistem tersebut dilengkapi dengan sensor suhu, sensor cahaya, lampu pijar dan blower. Konfigurasi sistem yang digunakan ditunjukkan pada gambar 2. Sementara algoritma pengaturan suhu dan intensitas cahaya yang dipakai ditunjukkan pada gambar 3. 


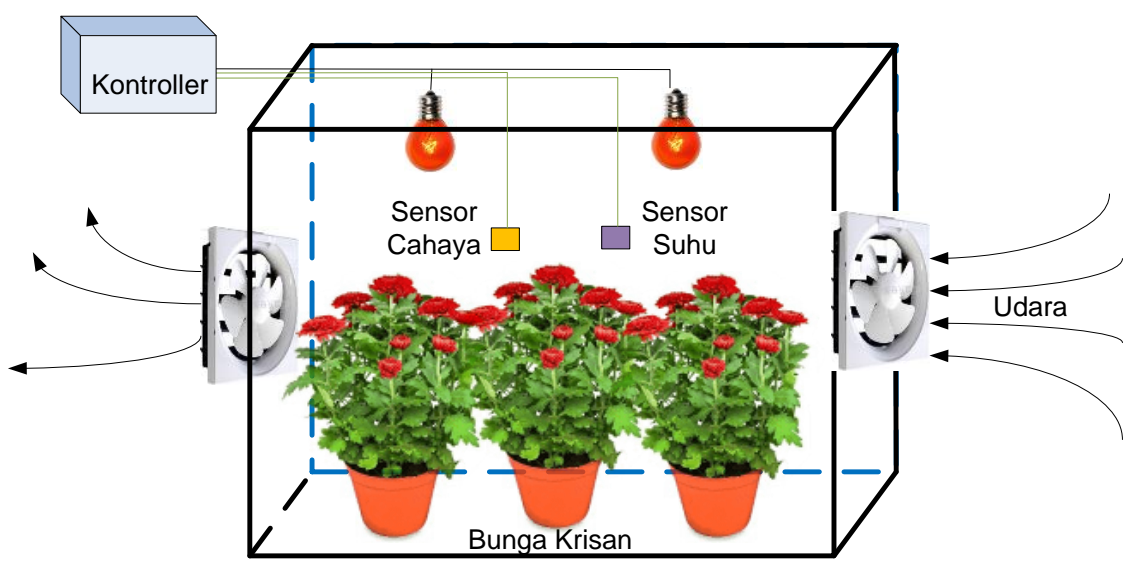

\section{Gambar 2. Konfigurasi Sistem Dalam Memanipulasi Lingkungan Hidup Bunga Krisan}

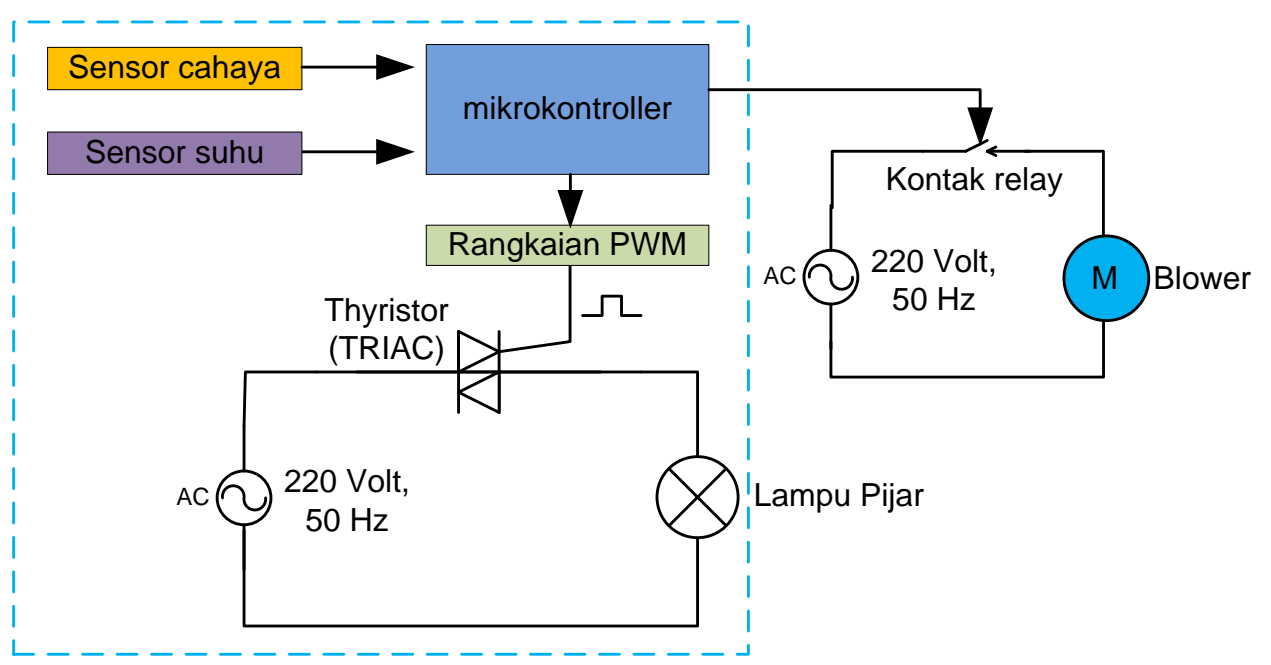

\section{Gambar 3. Konfigurasi Dimmer, Sensor Cahaya, Sensor Suhu dan Mikrokontroller}

Daerah lokasi budidaya bunga krisan yang cocok adalah dataran tinggi dan dataran medium. Kondisi cuaca di daerah dataran tinggi dapat berubah secara ekstrim. Perubahan suhu bisa mencapai sangat dingin, maka peran penghangat menjadi sangat penting. Pada ruangan budidaya, dalam mengatur suhu ruangan dapat dibantu dengan kipas untuk memperbagus respon pengaturan suhu ruang budidaya agar konstan yaitu 24 derajat pada siang hari dan 18 derajat pada waktu malam hari. Selain itu kipas juga difungsikan untuk sirkulasi udara agar tanaman juga mendapatkan pasokan gas karbon dioksida yang cukup bagi tanaman untuk dapat melakukan fotosintesis. 


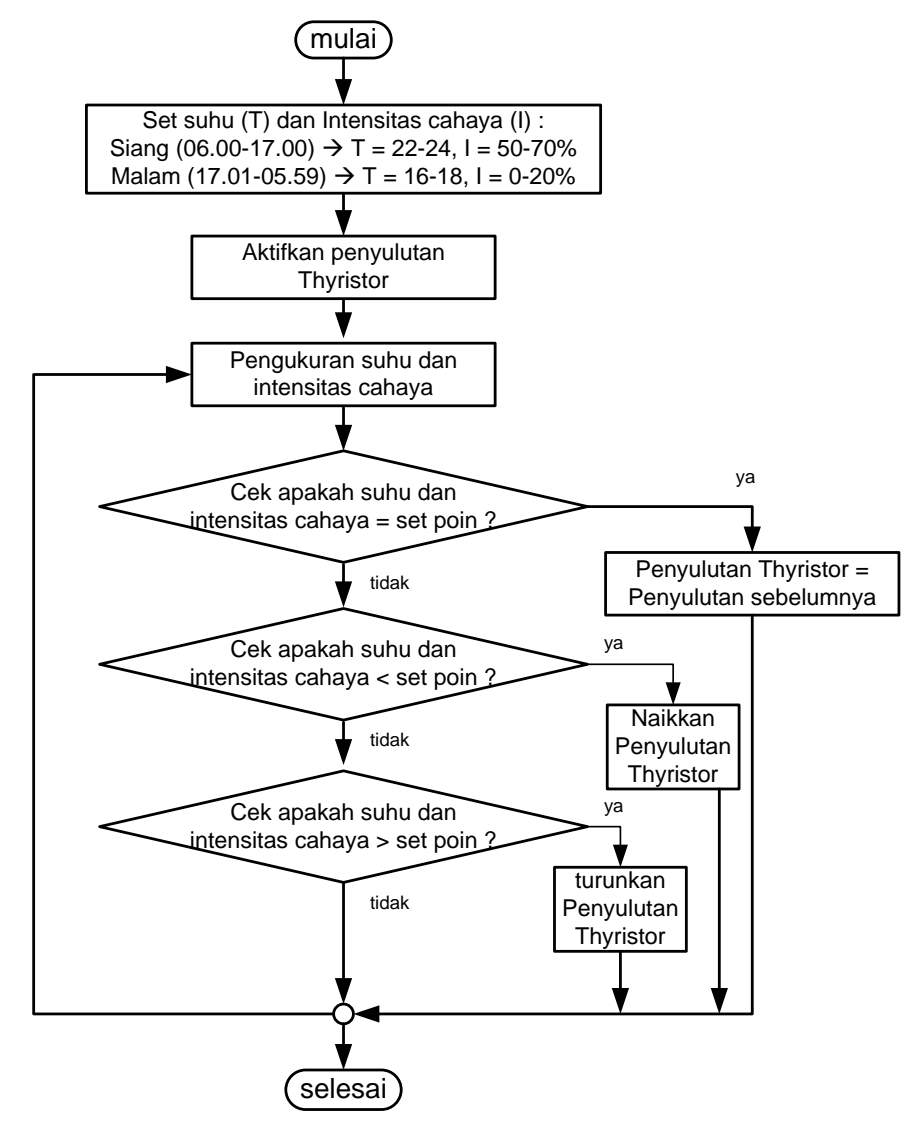

Gambar 4. Algoritma Program Pengaturan Suhu dan Intensitas Cahaya

Untuk daerah dataran tinggi kondisi cuaca ketika siang hari dapat berubah secara ekstrim. Ketika terjadi perubahan cuaca yang ekstrim, maka jangka waktu siang hari (penyinaran matahari) akan menjadi tidak menentu. Pada kasus tersebut, proses pergantian siang dan malam juga dapat diatur dan dijadwalkan dengan sinar lampu pijar yang dapat diatur penyalaannya. Sehingga perubahan cuaca yang ekstrim tidak lagi menjadi kendala dalam proses budidaya maupun pembungaan bunga krisan.

\section{KESIMPULAN}

Pengendalian suhu dan intensitas cahaya dilakukan dengan menyulut tryristor dengan sinyal PWM yang memiliki lebar pulsa tertentu. Penyulutan thyristor ini akan menyalakan lampu pijar dengan suhu lampu dan intensitas cahaya tertentu sesuai dengan lebar pulsa PWM yang dihasilkan oleh kontroller. Lebar pulsa PWM ditentukan dari pembacaan suhu dan intensitas cahaya ruangan oleh sensor suhu dan sensor cahaya. Set poin penentuan suhu dan intensitas cahaya diset sesuai dengan kondisi habitat terbaik bunga krisan. Setelah set poin ditentukan maka controller akan menentukan besarnya lebar pulsa yang akan ditriggerkan ke thyristor. Sehingga level suhu dan intensitas cahaya akan terkendali secara otomatis. Dari pemaparan proses manipulasi lingkungan budidaya bunga krisan dalam ruangan dengan menerapkan teknologi 
dimmer tersebut, dapat disimpulakan bahwa sistem tersebut dapat diterapkan pada daerah atau lokasi dengan perubahan suhu minimum 18 derajat. Selain itu tanaman bunga krisan juga dapat ditanam di ruangan tertutup atau gedung yang dilengkapi dengan pendingin AC sebagai tanaman hias dalam ruangan. Hal ini akan meningkatkan nilai estetika ruangan atau gedung.

\section{DAFTAR PUSTAKA}

[1] I. Wiguna, I. Wijaya, and I. Nada, "PERTUMBUHAN TANAMAN KRISAN (CRHYSANTEMUM) DENGAN BERBAGAI PENAMBAHAN WARNA CAHAYA LAMPU LED SELAMA 30 HARI PADA FASE VEGETATIF," BETA (Biosistem dan Tek. Pertanian), vol. 3, no. 2, pp. 1-11, 2017.

[2] Vina, "Pertumbuhan dan Pembungaan Krisan (Chrysanthemum sp.) Pada Berbagai Komposisi Media Tanam," 2016.

[3] Y. Nakano, Y. Higuchi, K. Sumitomo, and T. Hisamatsu, "Flowering retardation by high temperature in chrysanthemums: Involvement of FLOWERING LOCUS T-like 3 gene repression," J. Exp. Bot., vol. 64, no. 4, pp. 909-920, 2013, doi: 10.1093/jxb/ers370.

[4] J. U. D. Baloch, M. Munir, and M. Abid, "An appraisal of the use of reciprocal transfer experiments: Assessing the stages of photoperiod sensitivity in Pansy, Snapdragon, Petunia and Cosmos," Pakistan J. Bot., vol. 45, no. 2, pp. 421-426, 2013.

[5] C. Liu, J. Zhou, K. Bracha-Drori, S. Yalovsky, T. Ito, and H. Yu, "Specification of Arabidopsis floral meristem identity by repression of flowering time genes," Development, vol. 134, no. 10, pp. 1901-1910, 2007, doi: 10.1242/dev.003103.

[6] Syafriyudin and N. T. (Jurusan T. E. Ledhe, "Analisis Pertumbuhan Tanaman Krisan Pada Variabel Warna Cahaya Lampu Led," J. Teknol., vol. 8, no. 1, pp. 83-87, 2015.

[7] P. S. Nagare, S. Avinash, D. B. Bhadke, and P. P. T. Patil, "Controlling Ac Lamp Dimmer through Mobile," Int. J. Adv. Res. Electr. Electron. Instrum. Eng., vol. 5, no. 3, pp. 1528-1533, 2016, doi: 10.15662/IJAREEIE.2016.0503069.

[8] M. A. A. Mashud, D. Yasmin, M. A. Razzaque, and M. H. Uddin, "Automatic Room Temperature Controlled Fan Speed Controller Using Pt-100,” no. August, 2015.

[9] E. J. L. Costa et al., "Humidity control system in newborn incubator," 19th IMEKO World Congr. 2009, vol. 4, pp. 2577-2581, 2009. 